\title{
SOCIO-SUFISM OF ORANG MAIYAH: TOWARD HUMAN SOVEREIGNITY IN TOGETHERNESS
}

\author{
Rizqa Ahmadi \\ Department of Tasawuf dan Psikoterapi \\ Faculty of Ushuluddin, Adab, dan Dakwah \\ IAIN Tulungagung \\ Email: rizcoaham@gmail.com
}

\begin{abstract}
Among various religious groups in Indonesia is Orang Maiyah (Gathering Community) that has become a unique phenomenon. Cak Nun (Emha Ainun Najib) is the central figure in the community as well as the source of knowledge and inspiration for its members (although in so many occasion Cak Nun refuses to be called so). This paper explores the style of social Sufism teachings attached to the community approached by descriptive qualitative analysis. This work shows that Orang Maiyah, which is spread in various regions of Indonesia, has become a religiously motivated movement that brings people together to achieve a "sovereigned human" state of life. Cak Nun is not a sole magnet that lures the community members. The members of the community have a freedom to choose the paths of truth according to their own conscience through dialogue, discussion. They also exchange information from various sources provided by the Maiyah activities.
\end{abstract}

Keywords: Socio-Sufism, Maiyah, togetherness, sovereignty, charisma.

\section{BACKGROUND}

One may say that Muslims today are like froth. The assumption might be associated to the hadits by the Prophet Muhhamad who mentions that one day Muslims will have a situation in which they loose their power, although with a large quantity but the quality is not comparable. The mosque is spread everywhere but it only serves as a place of worship as a ritual, not for social activities. The preachers with various models and methods do not make the people excited to worship but actually makes them fragmented. The true Islamic mission as a carrier of peace seems to be and fierce. Indeed, Muslims are not fully aware that the spiritual crisis is engulfed. This is a unique phenomenon of spiritual crisis. Not that modern society is far from religion 
but the religion attached to them is limited as a label and identity, nothing more. Thus it can be said that the crisis of spirituality of modern society is not entirely due to the impact of social change or because of the influence of various sophistication and progress in the various lines of life that make people to be material-oriented but due to a lack of religious appreciation of the religion they believe in. This is as predicted by Prabu Joyoboyo, one of the sovereigns of the Kingdom of Mataram who is famous with his predictions about the future of Nusantara, that one day many people pray but do not understand what the prayers offered.

This kind of spirituality crisis has been responded by various circles in various ways. Among them is with the emergence of urban Sufism phenomenon that occurred in various regions, especially in urban society. They prefer innitiating religious activities that emphasize spiritual appreciation and reflection rather than formal rituals. One of the findings related to this is the research undertaken by Julia Day Howell (2000), Professor of the Sociology of Religion from Western Sydney University. The phenomenon of urban Sufism as promoted by Julia Day Howell, and Martin Van Bruinessen (2007) in his research in Indonesia, is defined as the birth of the urban middle-class spirituality movement against the background of Neo-Modernism. Their passion for spiritual expression is manifested in various activities such as remembrance $(\mathrm{d} z i k r)$, ritual, and wirid. This activity is done by those who are motivated to cleanse their soul (tazkiyat an-nafs). What is theorized is then becomes an academic debate because what Howell captures does not yet fully represent the variants of urban Sufism in Indonesia, more so in the world. But it at least represents the findings of modern society's response to the phenomenon of spirituality crisis.

Howel argued that a whole range of novel activities identified with 'Sufism' or tasawuf is now popular in Indonesia's major cities: from reading reflective and 'how-to' spiritual books, to attending academically-styled private courses, to joining informal prayer groups or healing workshops using $d z i k r$ chanting, to accepting the spiritual direction of non-traditional teachers outside the conventional tarekat. The key features of these new-style 'Sufi' activities are their stated link with sharia-based Islam, their pursuit of an experiential or 'inner' dimension to religious life, and a moving away from, or even rejection of, the supposed hierarchy, authoritarianism and 'other worldliness' of conventional tarekat. This last feature distinguishes the NeoSufism of past generations (that attempted merely to distance Sufism from idolatrous local practices and reassert the centrality of the syaria without attempting major institutional change) from this new 'Neo-Sufism'. The new 
'Neo-Sufism' (as some indeed call it; it is also called 'Tasawuf Positive' or 'Practical Sufism') responds specifically to the new conditions of Indonesian urbanism. Notwithstanding the ideological imperatives of nation building for an unambiguous, prescribed religious identity, people are propelled into privatized styles of religiosity by their experiences of social and geographical mobility, exposure to global economic forces and cultures, and participation in international cultural activities (Howell, 2000, p. 17).

What has been done by Howell and Bruinessen, and some other figures, have not fully represented the phenomenon of spiritual escape experienced by modern society, especially in Indonesia. Of course, there are many variants of other religious ways. For that, this paper is about to capture one of the kinds of social sufism style offered by Orang Maiyah which has various names and designations spread in various regions in Indonesia. This community is important to be studied because the pattern of its movement and the method of dawah they use are unique and different from those practiced by other communities. The community has also captivated various layers of society from different social classes.

\section{SOCIAL SUFISM}

Sufism as a practical formula of ihsān since its appearance has been debated, whether it comes from Islam or not. Nevertheless, in its development, scholars such as Trimingham (1998) asserted that the similarities of the teachings that exist in tasawuf with ideology outside Islam are not automatically called tasawuf or Islamic repertoire. Sufism retains its uniqueness and unique characteristics. In The view of J. Spencer Trimingham, Sufism is a natural progression in Islam, by borrowing a few sources of non-Muslims such as neo-platonism, agnosticism, Christian mysticism and so on. Despite that, Sufism remains with its own distinctive characteristics which are the doctrine of Islamic mysticism which leads to the principles of Qur'an and Prophetic tradition (Trimingham, 1998, p. 2).

The Trimingham opinion is also confirmed by Martin Van Bruinessen and Howel (2007). They mention that Sufism is the unique teaching of Islamic mysticism. It even looks like coming from the other mysticism teaching to the other religion or culture. It has the specific characteristic as mentioned by Bruinessen and Howel below.

"Islam's Sufi tradition cannot be equated simply with mysticism. As amply evident in this volume, as elsewhere, Sufism includes many different practice regimes and their supporting social institutions, arts 
and scholarly justifications. Nonetheless, the common thread through all is the possibility of heightened awareness of the Divine."(Bruinessen and Day Howell, 2007, p. 4).

At first, Sufism is more substantive as the Companions (sahabat) imitate the way of life of the Prophet or the Tabi'in imitating the way of life of the best Companion. Sufism has not been institutionalized in the future. Then Sufism reaches its peak when it has transformed into tarekat. It appears in two forms including tarekat and madhab. In that phase, there are two styles of Sufism that are so visible, namely philosophical Sufism and Sunni Sufism. Unfortunately the subsequent development of many tarekat begins to deviate from the proper teachings. So it then come the purification movement of the teachings of Sufism, such as the neo-Sufism movement. In addition, tasawuf is translated and applied to a variety of different ways of seeing and meaning. For example, because of Sufism is regarded as a cause of decline, provoking the emergence of ideas and thoughts about social sufism, actually the teachings of social sufism have existed from the beginning. Social sufism is interpreted as an attempt to expose the teachings of sufism with a more applicative, functional and contextual style. It is intersting to use Sulaiman term, one of the tasawuf reviewers from UIN Wali Songo Semarang in his research on the Gulen movement (as quoted by Ahmadi, 2016), he shows that Sufism now should no longer stay far on the sky but more earthy.

Ahmadi illustrates that social Sufism defined as the kind of Sufism that teaches some basic principles of the social dimension. The practical teaching of Sufism which is related to social dimension is al-itsar. There are several terms that can be associated with al-itsar including at-tafdhil (altruism), altrui (French) or alter (latin) or selflessly helping behavior. In Java it can be associated with the phrase of "Sepi ing pamrih rame ing gawe," a Javanese proverb that has a deep philosophy. It means that wherever possible we should be able to do for the benefit of others without expecting anything in return and appreciation whatsoever for his actions (Ahmadi, 2016, p. 69)Indonesia, "publisher-place": "Surakarta", "page": “67-73", "volume”: "I", "event": "Actualizing the Values of Humanism to Avoid the Global Terrorism", "event-place": "Surakarta", "abstract": "Modernization brings significant impact in many aspects, both positive and negative. The positive impact of modernization is the realization of life more effective, efficient, and practical. The negative impact is a multidimensional crisis, disintegration, and the crisis of spirituality. Spirituality crisis if not addressed, will damage the joints of life, including the norms that have been attached to the social community. Spirituality crisis that hegemonic majority of modern society responded by partially with tasawuf 
consciousness. Awareness of Sufism is the basic requirement faiths, including Islam. Many humans who know but not many are aware of the importance of tasawuf. Among the possibilities behind Sufism is about understanding patterns that still seem to be exclusive and limited. Sufism is considered synonymous with the life of solitude, seclusion and away from the sparkling life of the world. Social Sufism is a unique tradition of modern society. It is a development of Sufism which has a human characteristic, functional and contextual. Explores Sufism that fit the needs of modern society. This paper will describe the patterns of Social Sufism particularly Fethullah Gülen and Cak Nun's thought approach stronghold (as basic of society power. According to Amin Syukur, the characteristics of Social Sufism are contextual and transformative. Contextual sufism means more empirical and humanistic. In the 21 st century, according to Syukur, sufism movement is required to be more humanistic, empirical and functional. Appreciation of the teachings of Islam is not just reactive, but active and gives direction to the attitude of human life in this world, whether it is moral, spiritual, social and economic. When sufism becomes a breakout from the visible world to the spiritual world, it can be regarded as a reaction and social responsibility, the obligation to perform tasks and to respond to social problems (Syukur, 2004, p. 20).

At least there are three sources of value that can represent practical teachings of social sufism including As-Shuhbah, Al-Futuwwah, and Al-İtsar. They should be easily found in some ancient mystical texts such as Ar-risālah, the magnum opus of Imam al-Qusyari, 'awārif al-Mäārif As-Syuhrowardi and Fushus alHikam Ibn Arabi. Firstly, As-Shuhbah means Brotherhood, solidarity, and friendship. It has become a Sufi tradition. In the Sufi tradition, it is strongly recommended to be friendly with people who can show their weakness and badness. The role of the murshid in a tarekat is very vital in educating and showing the truth to the disciples. According to As-Suhrawardi, friendship works positively opening the inner pores, so that a person can gain knowledge about the new parasites that encounter him (as quoted by Ahmadi, 2016).

Secondly is Al-Futuwwah. The word al-futuwwah is derived from the word fata which means youth or powerful youth. Futuwwah also can mean strength or toughness. It also can be interpreted with generosity and the honor. According to Abdul Aziz Muhammad, futuwwah can be understood in two perspectives. The first strength of the material/physical (alquwwah al-mädiyyah) and the second, the power of meaningful/non-physical (alquwwah al-ma'nawiyah) (Muhammad, 1998, p. 6). This material or physical strength may include courage and toughness. The first can be found in the character of Arab youth pre-arrival propagation of Islam. Thirdly is Al-İtsar. According to Ahmadi, al- 
$\bar{i} t \bar{s} \bar{r}$ is a synonym of altruism with a more complex meaning. He mentions it in his work as can be found below.

"The practical teachings of Sufism which are the social dimension is al-ìtsār. There are several terms that are commensurate with al-ìtsār, namely at-tafdhil (altruism) altrui (French) or alter (latin) or selflessly helping behavior. In the realm of Java can be synchronized with the phrase "Sepi ing pamrih rame ing gawe." Javanese proverb that has a deep philosophy. Wherever possible we should be able to do for the benefit of others without expecting anything in return and appreciation whatsoever for his actions (Ahmadi, 2016, p. 69)Indonesia'"'publisher-

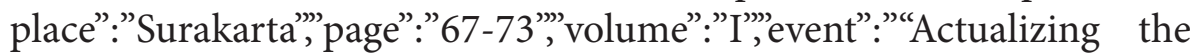
Values of Humanism to Avoid the Global Terrorism"'”',event-place":"S urakarta','abstract":"Modernization brings significant impact in many aspects, both positive and negative. The positive impact of modernization is the realization of life more effective, efficient, and practical. The negative impact is a multidimensional crisis, disintegration, and the crisis of spirituality. Spirituality crisis if not addressed, will damage the joints of life, including the norms that have been attached to the social community. Spirituality crisis that hegemonic majority of modern society responded by partially with tasawuf consciousness. Awareness of Sufism is the basic requirement faiths, including Islam. Many humans who know but not many are aware of the importance of tasawuf. Among the possibilities behind Sufism is about understanding patterns that still seem to be exclusive and limited. Sufism is considered synonymous with the life of solitude, seclusion and away from the sparkling life of the world. Social Sufism is a unique tradition of modern society. It is a development of Sufism which has a human characteristic, functional and contextual. Explores Sufism that fit the needs of modern society. This paper will describe the patterns of Social Sufism particularly Fethullah Gülen and Cak Nun's thought approach stronghold (as basic of society power.

Al-İtsar can also be interpreted as loving others as oneself'. The principle of itsar>s behavior rests from a worldview taken from the word of the prophet that one's faith is imperfect as long as he has not loved his brother as he loves himself (lā yukminu ahadukum hatta yuhibbu liakhīhi mā yuhibbu linafsihi).

Within social sufism, one of the theories offered by Amin Syukur is the theory of social responsibility. Social responsibility is so important because through their responsibilities human beings will have integrity. Everyone should realize that he is a creature who can only survive with a sense of responsibility to each other. The responsibility will bear a strong fraternal bond among human beings with one another. In the context of sufism, social responsibility 
developes meanings within the context of time and social change, especially in modern life. The dynamic of social life following increasingly by the social issues requires everyone to follow the flow of these changes without having to fall to the error or failure. Humans have to be smart to read the social phenomenon. It should also provide a significant contribution to the surrounding environment and community. In the modern era it is true that people will find an ideological war. It is a battle of ideas; how to look at life and solve social problems with various alternative solutions. Those idea certainly have a style and an extensive background in accordance with the originator of the idea.

Amin syukur divides responsibilities into five categories; spiritual responsibility, ethical responsibility, intellectual responsibility, political responsibility and pluralism responsibility. The responsibility in Sufism is not to escape from real life as alleged by some people who disagree with sufism but it will remain an attempt to arm ourselves with new spiritual values. These spiritual values will fortify themselves in the face of problems in a materialistic life. In Sufism, there are positive principles that are capable of developing the future of human beings such as introspection (muhāsabah), both in vertical and horizontal problems. Moreover, sufism provides doctrines for always doing $d h i k r$ and actualizing it in a broader meaning. And sufism is a source of motion, normality, motivation, and source of value that can be used as a reference of life (Syukur, 1999, p. 114). Ethical responsibility is meant for those practizing sufism to always feel that morality in life is a necessity. Intellectual responsibility is encouraging people to not only be a spiritual conscious human being but also a conscious of reason or mind. And political responsibility means to get involved both directly and indirectly in political affairs and no matter how small the contribution. And the pluralism responsibility is interpreted to accept differences and diversity because the essence of difference and diversity is sunnatullah.

\section{MULTILATERAL AUTHORITY, OBEDIENCE AND ORANG MAIYAH.}

The theory of authority and obedience is popular in the social studies proposed by Weber. Although Weber discusses such theories in the sphere of politics and power, they are commonly used in the analysis of religious societies. According to Weber (1978), a certain legitimacy and authority in a particular society are divided into three categories. Traditional, charismatic, and rational-legal. Weber argument below is important.

There are types of legitimate domination. The validity of the claims to legitimacy may be based on 1. Rational ground, resting on a belief in 
the legality of enacted rules and the right of those elevated to authority under such rules to issue commands (legal authority); 2. Traditional grounds, resting on an established belief in the sanctity of immemorial tradition and the legitimacy of those exercising authority under them (traditional authority); or finally, 3. Charismatic ground, resting on devotion to the exceptional sanctity, heroism, or exemplary character of individual person, and of the normative patterns or order revealed or ordained by him (charismatic authority) (Weber, 1978, p. 215).

Weber in his speeches entitled "Politics and as a vocation" and "Economy and society" explains that there are many theories about the elements of the obedience. According to him, obedience occurs because of three things including empathy, inspiration and persuasion using rational arguments or combining three ways at once (Weber, 1978, p. 946).

Turner (Turner, 2012, p. 367) explains that the compliance theory sketch parallels with the analysis of a wider legitimacy domination again and produces models of basic obedience with more abstract as can be seen below.

\begin{tabular}{cc}
\hline Domination & Obedience \\
\hline Tradition & Empathic \\
\hline Charisma & Inspirational \\
\hline Bureaucratic & Rational \\
\hline
\end{tabular}

Further, Turner reveals that adherence to the running domination is a very complex social phenomenon. The motivation to comply is not just a matter of perception to the legitimate orders of the superior alone but could be due to factors of apathetic compliance, pragmatic, fear of punishment or because it was considered reasonable (Turner, 2012, p. 367). This view is to support the idea that multilireal authority is related to obidience that is now being discussed within Orang Maiyah.

The phrase of Orang Maiyah is attributed to the cross-theme discussion community with Emha Ainun Nadjib (hereinafter referred to as Cak Nun), such as politic, economy, social, culture and certainly religion or religious experience although in its development, Maiyah should not be identified with Cak Nun. Orang Maiyah also was known as jamaiah Maiyah or the group of Maiyahan. Maiyah derived from the Arabic language, ma'a, ma'iyyatun which mean mushahabatun that is friendship or brotherhood. The community members are spread out into some regions in Indonesia with a different name. In Jakarta for example, the group is called Kenduri Cinta. The name of Mocopat Syafaat is for the group found in Yogyakarta, Padhang Mbulan 
in Jombang, Gambang Syafaat in Semarang, Bangbang Wetan in Surabaya, Jamparing Asih in Bandung, Paparandang Ate in Mandar, Maiyah Baradah in Sidoarjo, Juguran Syafaat in Banyumas Raya and Maneges Qudroh in Magelang. Regularly Orang Maiyah holds discussions every two weeks or once a month (Ahmadi, 2016, p. 71)Indonesia'”'publisher-place":"Surakarta"'”page":"6773'”'volume":"' '"'event":"'Actualizing the Values of Humanism to Avoid the Global Terrorism,'”',event-place":"Surakarta'”'abstract":"Modernization brings significant impact in many aspects, both positive and negative. The positive impact of modernization is the realization of life more effective, efficient, and practical. The negative impact is a multidimensional crisis, disintegration, and the crisis of spirituality. Spirituality crisis if not addressed, will damage the joints of life, including the norms that have been attached to the social community. Spirituality crisis that hegemonic majority of modern society responded by partially with tasawuf consciousness. Awareness of Sufism is the basic requirement faiths, including Islam. Many humans who know but not many are aware of the importance of tasawuf. Among the possibilities behind Sufism is about understanding patterns that still seem to be exclusive and limited. Sufism is considered synonymous with the life of solitude, seclusion and away from the sparkling life of the world. Social Sufism is a unique tradition of modern society. It is a development of Sufism which has a human characteristic, functional and contextual. Explores Sufism that fit the needs of modern society. This paper will describe the patterns of Social Sufism particularly Fethullah Gülen and Cak Nun's thought approach stronghold (as basic of society power.

They also have some definitive Maiyah activities conducted in Jombang, Yogyakarta, Semarang, Jakarta and Surabaya. For tentative activities, they also have meeting every two or three months in the tens or even hundreds of other places, in the country and abroad (Nadjib, 2016, p. 17). Each region held their meetings on different times based on their specific characteristic. This community performs a variety of deconstruction understanding of the values, communication patterns, methods of cultural transformation, educational way of thinking, which is also interspersed with artistic performances of Kiai Kanjeng, such as music and poetry readings. Orang Maiyah also work with deploying solutions to problems. Maiyah activities or programmes are attended not only by Muslims but also those belonge to other religions and interfaith leaders. Their forums are open to anyone who wishes to attend although they are from different religious backgrounds and are ethnically and culturally different.

To introduce Maiyah, there is a unique quote by Cak Nun which is the key to 
interpreting it. "Lebih baik saya nyolikin lombok rawit ke mulut Orang Maiyah daripada duduk menerangkan dan mengurai panjang lebar tentang makna lombok kepada mereka" (Nadjib, 2016, p. 2) (Preferably I put chili into the mouths of Orang Maiyah than sitting for a long time to explain and unravel about the meaning of chili to them). In the other words it means that Maiyah will be more easily understood by everyone with participating and involving in the activities held by the group. Even though Maiyah can be interpreted with various interpretations but all the members have the same goal; to seek the truth together from anyone and from anywhere. Furthermore, Cak Nun said that Maiyah is the dynamic interpretations without ending, so there is no question of "what is Maiyah". That is both raw and frozen. Although there can be a "regulation" applies to certain particular time and space to the design of a particular value, but it is only a point followed by the next point by point to immortality (Nadjib, 2009).

\section{HUMAN SOVEREIGNITY AND TOGETHERNESS}

It is uderstood that Marxism considers religion as an opium. Prabu Joyoboyo (as quoted by Ahmadi, 2016) also predicts that one day most people will be crazy with prayers but do not understand the meaning of the prayers they are praying. It is not entirely wrong because in that time, the religion is often used as a political vehicle, a tool of power to oppress and deceive the public. Religion seems to kill human consciousness and prevent people from progressing. And it is really happening in today's world. Many people live with excessive fanaticism in religion. A religion that should inspire its followers to be a moral person to all beings seems not true but is in the opposite situation. There is nothing wrong with the teachings of religion. The thing is that religious practitioners do not get the right teachings of a religion that they practice, I assume.

In Islam, there are various understandings and methods of understanding Islam including using textual or and contextual approaches. Those approach are formulated in various methods of dawah. Among the different ways of understanding Islam, Maiyah is a rare phenomenon. Maiyah has a special religious pattern. For most people, Maiyah is a unique way of learning life and diversity. The uniqueness is seen in several attributes attached to it, including how to internalize values or approaches, and methods used. In the Maiyah, some values are introduced including the internalization of various good values such as about the gratitude that becomes the foundation of happiness, respect for others who disagree and awaken the importance of culture and tradition. The importance of social responsibility is very complex, eliminating 
the egoism and various other noble values that modern people began to crumble in their life.

According to Arfian Bayu Bekti, based on his research conducted on Maiyah Mocopat Syafa'at in Bantul Yogyakarta, there are several internalizations of religious humanist education within the community of Maiyah. Those values include egalitarian (unity), aesthetics (beauty), creativity, morals, aqìdah, and nationalism. Internalization of these values is done by the dialogical approach, cultural approach, multicultural, and holistic approach (Bekti, 2014, p. vii). For Cak Nun, Maiyah is not deliberately formed with certain and special formulas. Maiyah is not a religious organization, religious school, tarekat, or religious sect. Maiyah has no binding and rigid rules. Maiyah also does not have a systematic organizational structure. Maiyah is a continuous and dynamic process of truth and authenticity-seeking.

Cak Nun (as quoted by Nadjib, 2009), simply states that:

"Di dalam diri saya Maiyah saya niati menjauh dari mempersaingkan diri dengan gerakan sosial, kemanusiaan, intelektual atau spiritual apapun, tidak merebut apapun dan tidak berkehendak menguasai apapun di dalam kehidupan bermasyarakat atau bernegara" (Nadjib, 2009).

"With me the Maiyah does not mean to be away from competing with any social movement, humanity, intellectual or spiritual; it does not seize anything and is not meant to take over anything within any society or state."

According to Cak Nun, indeed, Maiyah is the attempt of each perpetrators, individually or working together, to seek and find the precise position and justice of relationships with God, fellow beings, the universe and himself. Maiyah is only a symbol that leads te people of Maiyah to realize the importance of religion perfectly by searching and discovering in totality within the self and the environment. He also explains that the search and discovery of various things are dynamic, independent, dialogical, without an end of the road, no space boundaries, no design and time targets. It is, because all of it is a journey of longing to the true and eternal. (Nadjib, 2009).

The role of the individual in Maiyah teaching is central and appreciated. They are aware of their individual singleness because every individual is incomparable. Every Orang Maiyah believes that they have the temporary life and borrow the right of living from the real owner of the life (God) to stop at a historical coordinate (Redaksi Bangbang Wetan, 2017). Although individual roles and individual potentials within the Maiyah are very important, Maiyah teaching encourages all mebers to consciously eliminate their attitude of ego. 
This attitude is an awareness of social responsibility. This attitude of selfishness will erode self-esteem and feeling better than others. In the Maiyah there is no teacher and no disciples but all are students. The learning process can be done through learning sources anywhere and from anyone without any special treatment for special groups of superior and degrading the inferior.

The Maiyah people learn from both people who are knowledgeable and people who are considered as ignorant. It is the case that because of learning process many young people could be having an adult minded way of thinking, and like wise. Sometimes a person's maturity is not in line with his intellectuality (Nadjib, 2016, p. 3). For Cak Nun, life and science are endless spheres. And every point on its surface, inside, outside or in any part of the infinite sphere is the door of science. The secret path to the living reality is what he Maiyah call as the one God (Nadjib, 2016, p. 12). There is nothing that does not bring us benefit and knowledge. Science can be obtained from anyone regardless of social status, intellectual level, and position in a society.

With such a position, Cak Nun's role in the community is not different from other Maiyah members. Cak Nun refuses to be called as a teacher, central figure, murshid, or the like. He said that all members of Maiyah are students looking for enlighnment. They try to find the truth with continuous reasoning by exploring self-potential and dialogue with the other. And the process of finding the truth will strengthen one another. Maiyah people are eager to find knowledge, wisdom, love, happiness. They say that understanding God is enough by looking at their teeth in the mirror that make them thankful that God took the decision not to let the teeth continue to grow (Nadjib, 2016, p. 14). The process that must be done by every Maiyah people to achieve their goals is to witness what Cak Nun call as the "seven heavens in the self." Cak Nun invites all audiences to try to be the person through this order of position; knowing -> understanding -> getting -> able -> willing -> sincere -> and happines. He believes that by doing the mentioned orner of position hierarchically, a man can be truly aware of his existence and his position as a true man.

Furthermore, in term of Sovereignty in togetherness, Rizqa Ahmadi (2016) argues that as a philosophy term of Maiyah, togetherness and militant in this community are very visible. The togetherness that involved not only to say hello and only meet each other but also to exchange opinions and deep understanding about the teachings of the religions they practice. All who attend the Maiyah's events are considered as a source of knowledge. Every participant can have enlightening each other. Cak Nun sometimes acts as an agent that transmit piety and godliness to the audience which is then transmitted to the others. In 
order to foster the potential of the people, Cak Nun combines some aspects of life inlcuding art, religion, education, political, and economic. He also includes in his views the deconstruction of understanding of values, communication patterns, methods of cultural relationship, educational way of thinking, as well as in deploying solutions to community problems (Ahmadi, 2016: 71)

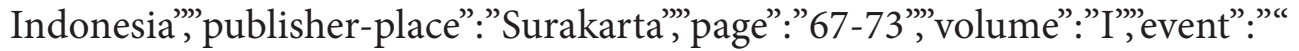
Actualizing the Values of Humanism to Avoid the Global Terrorism"','”event-pl ace":"Surakarta"',abstract":"Modernization brings significant impact in many aspects, both positive and negative. The positive impact of modernization is the realization of life more effective, efficient, and practical. The negative impact is a multidimensional crisis, disintegration, and the crisis of spirituality. Spirituality crisis if not addressed, will damage the joints of life, including the norms that have been attached to the social community. Spirituality crisis that hegemonic majority of modern society responded by partially with tasawuf consciousness. Awareness of Sufism is the basic requirement faiths, including Islam. Many humans who know but not many are aware of the importance of tasawuf. Among the possibilities behind Sufism is about understanding patterns that still seem to be exclusive and limited. Sufism is considered synonymous with the life of solitude, seclusion and away from the sparkling life of the world. Social Sufism is a unique tradition of modern society. It is a development of Sufism which has a human characteristic, functional and contextual. Explores Sufism that fit the needs of modern society. This paper will describe the patterns of Social Sufism particularly Fethullah Gülen and Cak Nun's thought approach stronghold (as basic of society power.

Barikur Rahman (2013) mentions that people have some motivations as the attend Maiyah activities. Some believe that Maiyah is a means of entertainment. Some other say that it is a religious call and as a means of the social and intellectual process. As found in the practices of the Maiyah, people do not get involved in religious activities only but also in a series of events in the same time such as poem demonstrations, musical performances, idea sharing, standup comedy, and so forth. Interestingly, all of the activities have some inserted values that become the reflection of all participants. In Mocopat Syafaat, for example, Rahman mentions that maiyahan activities include religious and social activities. He explains that religiosity is not defined as the activity which is based on ritual worship only but rather how to apply the religious knowledge into the conditions and social relationships. Religiosity is not measured in the terms of quality and quantity in the ritual of worship only. It is also related to religious insight as a person is able to communicate a social action and good ethical value in daily life. Rahman also shows that religiosity is related to cultural aspects, good values, norms and customs prevailing in 
the society as Jamaiah Maiyah consists of various social categories based on different backgrounds (Rahman, 2013: 52-53).

Misunderstanding is found in the public discourse that the Maiyah activity is more influenced by Cak Nun as the charismatic central figure. In fact, people have their freedom in the community. Cak Nun as the central figure of this community does not show his authority to his followers. Here is what he said.

Maiyah was not a religion, nor even becoming a new religion. I never mean it as a theological schools or madzhab. I never create Maiyah to be tarikat (sufi order), sects of worship, and the mass organizations, political institutions or any kind of social institution. However, I am not in any position to have the right to require or prohibit Maiyah to be a certain thing, because the presence of the Maiyah is required by its own values (Nadjib, 2009).

Orang Maiyah come together once a month for five to seven hours without being invited to gather. The join in the Maiyah based on their spirit of seeking what is right, not who is right. They come and have the gathering supprted by their obedience which, in the concept of tasawuf, can be categorized into a call of fulfilling the responsibility of spirituality, intellectual responsibility, moral responsibility, political responsibility, or plurality responsibility. This sense of responsibility encourages them do join without having to think about the benefits they would get. They rather have an attitude to keep life running with dynamic and harmony, asca servant ('abd) and deputy of God (khalifatullah).

The members of Maiyah are not bound by a rigid rule but togetherness. They are being channeled to 'not looking for who is right but what is right'. Normally, when receiving information, people of Maiyah will have a 'right' or 'wrong' reaction and then 'believe' or 'do not believe'. In this case, Maiyah encourages each individual to process it (with a methodology that contains the principle of 'not looking for who is right but what is right'). I have come to a conclusion that the community is based on sovereignty and independence. Averyone can be a teacher and any theory is accepted as a discourse for each individual to discover the truth. An understanding and life experience will confirm the truth (Redaksi Bangbang Wetan, 2017). Among the pillars that carry the values of sovereignty in the community is that in the Maiyah there is no obligation to obey the figure (Cak Nun). Every individual has their own meaningfulneed. Heterogeneity in the composition of Maiyah members is also an important part of distancing the attitude of sectarianism and fostering the spirit of togetherness regardless of the difference. The group is upholding plurality and diversity. People who attend Maiyah are not only Muslims but 
those having multi-religious and ethnic backgrounds. Maiyahan is open and liked by various groups of people. They come from differnt social categories, various belief, and religious backrounds. The topics of discussion in Maiyah gethering are based on in real social problems in the life of the community. People talk about things on the basis of everiday life experience. And then the results of that discussion can be applied in everyday life.

From the description of the uniqueness in the practice of Maiyah, it is apparent that the charisma of Cak Nun is not the only one that binds the Maiyah members to participate in the activity but only one side of the magnet. The other side of the magnet is even much stronger than just his figure. A very dominant magnet is the power of openness and an opportunity for anyone to seek answers to various religious and social issues independently, sovereignty, without interference from others. In this connection, Cak Nun said: "Discover and realize your unity in the immediate environment, within society, in your nation. If there are still questions, God will help cover your questions with the strength from Him. And you may say Ya dzal wabal ya dzal wabal ya dzal wabal (one of the dzikir readings popularized by Cak Nun) (Nadjib, 2009). Internalization of values that later become the guideline of human life lies in the process of dynamics and the ongoing transfer of knowledge from one person to another. The power of the individual is appreciated together with the power of the togetherness. People are being bound by the value of togetherness and become the unity which then create alignment and harmony. The continuity of the process has helped the Maiyah community to grow bigger than just a group of organizations, pesantren, or a particular community.

\section{CONCLUSIONS}

A prominent feature of the study that has been done on Maiyah people is that the community awakens people to become sovereign human beings. Every human is created by God with their own unique perfection. And of course at the same time they are also equiped with various potentials. Every Orang Maiyah realizes that all members have advantages. The process of learning in the community is to search independency and togetherness on an ongoing basis. Understanding the experience that goes through with other members is important so that it can lead to a truth that is being hoped. In other words, the output of all processes in Maiyah is the sovereignty of the individual within the Maiyah. The sovereignty is gained by the togetherness. In the togetherness, they build basic instincts; they identify, then they have a conclusion, which may be the same. Togetherness within the Maiyah helps enrich the view that will grow and reinforce the individual's sovereignty. 


\section{BIBLIOGRAPHY}

Ahmadi, R., (2016). Socio-Sufism and Social Change Movements in Modern Society (A Study on Fethullah Gülen and Cak Nun's Thought), in International Conference on the Middle East and Southeast Asia (ICOMS) 2016. Presented at the Actualizing the Values of Humanism to Avoid the Global Terrorism, Arabic Department Faculty of Cultural Sciences Universitas Sebelas Maret Surakarta, Indonesia, Surakarta, pp. 67-73.

Bekti, A.B. (2014). Pendidikan Humanis Religius dalam Kegiatan Maiyah Mocopat Syafaat di Bantul. Yogyakarta: UIN Sunan Kalijaga.

Bruinessen, M. van, Day Howell, J. (Eds.), 2007. Sufism and the "modern" in Islam, Library of modern Middle Eastern studies. London: Tauris.

Howell, J.D., (2000). Indonesia's Urban Sufis: Challenging Stereotypes of Islamic Revival. ISIM Newsletter.

Muhammad, A.A., (1998). al-Futuwwah fil-Mafhum al-Islami. Alexandria: Dar al-Wafa lid-Dunya.

Nadjib, E. A. (2016). Orang Maiyah. Yogyakarta: Bentang Pustaka.

Nadjib, E.A. (2009). Orang Maiyah dan Gerbang Ghaib [WWW Document]. Httpwwwpadhangmbulancomtopicskolom-Emha.

URL http://www.padhangmbulan.com/topics/kolom-emha/

Rahman, B. (2013). Konstruksi Sosial Religiusitas (Studi tentang Religiusitas terhadap Jama'ah Maiyah di Yogyakarta). Yogyakarta: Jurusan Sosiologi Fakultas Sosial Ilmu Politik Universitas Gajah Maada.

Redaksi Bangbang Wetan, (2017). Kedaulatan Manusia Maiyah. Yogyakarta: Bangbang Wetan Majelis Masy. Maiyah.

Rubaidi, R. (2016). "Reorientasi Ideologi Urban Sufism di Indonesia terhadap Relasi Guru dan Murid dalam Tradisi Generik Sufisme pada Majelis Shalawat Muhammad di Surabaya." Teosofi Jurnal Tasawuf Dan Pemikiran Islam 5, 294. doi:10.15642/teosofi.2015.5.2.294-320

Syukur, A. (1999). Menggugat tasawuf: sufisme dan tanggung jawab sosial abad 21. Yogyakarta: Pustaka Pelajar.

Syukur, H.M.A. (2004). Tasawuf sosial. Yogyakarta: Pustaka Pelajar.

Trimingham, J.S. (1998). The Sufi Orders in Islam. Oxford: Oxford University Press. 
Turner, B.S. (2012). Relasi Agama dan Teori Sosial Kontemporer. Yogyakarta: IRCiSoD.

Weber, M. (1978). Economy and Society: An Outline of Interpretive Sociology. California: University of California Press. 
